\title{
ANALISIS KANDUNGAN FORMALDEHID DALAM MINUMAN DENGAN KEMASAN PLASTIK POLYETHYLEN TEREFTALAT (PET) YANG BEREDAR DI KODYA PEKANBARU
}

\author{
Itnawita, T. Abu Hanifah, Amelia, Khoirul, Eriesa \\ Laboratorium Analitik, Jurusan Kimia, FMIPA, Universitas Riau \\ Jln. Raya Bangkinang KM 12,5 Pekanbaru 28293 \\ E-mail: itna_05@yahoo.co.id
}

\begin{abstract}
ABSTRAK
Salah satu kelemahan dari plastik Polietylen tereftalat (PET) yang digunakan sebagai kemasan minuman adalah terjadinya migrasi monomer-monomer berupa formaldehid dan asetaldehid selama penyimpanan. Dari hasil penelitian terhadap beberapa jenis minuman dengan kemasan PET yang beredar di Kodya Pekanbaru menunjukkan terjadinya peningkatan kandungan formaldehid dalam minuman selama penyimpanan. Kandungan formaldehid dalam minuman yoghurt yang disimpan sampai 70 hari adalah 1,488 mg/L dan dalam HDPE 3,250 mg/l, minuman berkarbonat $2,31 \mathrm{mg} / \mathrm{l}$ dan air mineral $0,27 \mathrm{mg} / \mathrm{l}$ yang disimpan selama 30 hari dalam keadaan terpapar matahari. Penyimpanan minuman joghurt, dan minuman berkarbonat setelah 50 hari telah melebihi NAB yang ditetapkan oleh tiga lembaga organisasi di PBB yaitu ILO, UNEP serta WHO yaitu $1 \mathrm{mg} / \mathrm{L}$. yang diperbolehkan. sedangkan air mineral masih berada dibawah standar.
\end{abstract}

Kata Kunci: Polyetylen Tereftalat, formaldehid, migrasi

\section{PENDAHULUAN}

Plastik menjadi suatu wadah atau kemasan yang populer digunakan di kalangan masyarakat. Plastik mempunyai beberapa keunggulan antara lain tidak berkarat, mudah dibentuk, kuat, ringan, dapat diberi label atau dicetak sesuai dengan kreasi dan dapat dibuat transparan. Ada beberapa jenis plastic yang umum digunakan seperti polyetylen tereftalat (PET) dan poli propilen (PP). Plastik polietilen tereftalat dibuat dari polimer poliester yang dihasilkan dari reaksi antara etilen glikol dengan asam tereftalat atau dimetil tereftalat dengan menggunakan katalis seperti garam $\mathrm{Mn}, \mathrm{Co}, \mathrm{Cd}, \mathrm{Pb}$, dan lain-lain ( Artha,2007 ). Polietilen dibuat

$$
\mathrm{OOCC}_{6} \mathrm{H}_{4} \mathrm{COOCH}_{2} \mathrm{CH}_{2} \mathrm{OH} \rightarrow-\mathrm{OOCC}_{6} \mathrm{H}_{4} \mathrm{COOCH}=\mathrm{CH}_{2}+\mathrm{H}_{2} \mathrm{O} \text { (1) }
$$

$$
\rightarrow \mathrm{OOCC}_{6} \mathrm{H}_{4} \mathrm{COOH}+\mathrm{CH}_{3} \mathrm{CHO}
$$

Uzairu dkk (2010) menemukan kandungan formaldehid dalam minuman bir dengan proses polimerisasi adisi dari gas etilen yang diperoleh sebagai hasil samping dari kegiatan industri dan minyak. Plastik polietilen tereftalat dan polietilen banyak digunakan untuk kemasan minuman karena bisa di pakai dalam jangka waktu tertentu. Namun demikian, plastik menyimpan kelemahan disebabkan adanya migrasi zat monomer pada plastik ke dalam makanan ataupun minuman selama penyimpanan (Azriani,2006). Migrasi ini akan lebih cepat terjadi jika lingkungan dalam minuman atau makanan tersebut mengandung materi yang mampu mempercepat tejadinya pelepasan rantai monomer (Duncans, 2000). 
(2006) adanya migrasi formaldehid dari kemasan kedalam minuman air mineral dari jepang yaitu formaldehid (10,1-27,9 ppm) dan asetaldehid (44,3-107,8 ppm). Villain dkk (1994) meneliti degradasi PET dengan berbagai suhu dan terbentuknya senyawa mudah menguap salah satunya dapat terbentuk formaldehid. Lawrence dkk (1983) menemukan bahwa kandungan formaldehid pada soft drink kemasan plastik lebih tinggi (8,7 ppm) dari pada bir kemasan botol $(0,46$ ppm).

Formaldehid adalah gas yang mudah terbakar, tidak berwarna, memiliki bau yang tajam, mudah larut didalam air dan sangat reaktif dengan banyak zat ( Mujiarto,2005). Formaldehid mempunyai sifat racun bagi manusia pada konsentrasi tinggi yaitu di atas $1 \mathrm{mg} / \mathrm{L}$ yang akan mengganggu saluran pernapasan, mata dan kulit ( Rianto, 2009). Untuk itu diperlukan suatu metoda yang cocok untuk penentuan kadarnya. Spektrofotometri dipilih karena waktu pengerjaannya yang cepat, selektif, sensitive.

\section{METODOLOGI PENELITIAN}

Sampel diambil dari beberapa supermarket di Kota Pekanbaru secara acak (random sampling). Sampel yang diambil adalah minuman yoghurt, minuman berkarbonat dan air mineral yang dikemas dalam wadah polyethylene tereftalate (PET). Analisis migrasi formaldehid diuji melalui analisa kandungan formaldehid dengan menggunakan reagen Schiffs dan pengukuran dengan metode Spektrofotometri. Analisis dilakukan pada rentang waktu tertentu tergantung masa kadaluarsa masing-masing sampel.

Bahan yang digunakan dalam penelitian ini asam klorida $(\mathrm{HCl})$ pekat, asam fosfat $\left(\mathrm{H}_{3} \mathrm{PO}_{4}\right) 10 \%$, formaldehid standar $37 \%$, reagen schiff's (asam fuksin, $\mathrm{NaSO}_{3}, \mathrm{HClp}$ ), asam sulfat $\left(\mathrm{H}_{2} \mathrm{SO}_{4}\right)$ pekat, akuades, Alat yang digunakan meliputi Spektrofotometer (Thermoscientific Genesys 20), timbangan analitik (Mettler AE 200), seperangkat alat destilasi dan seperangkat peralatan gelas yang umum digunakan.

\section{Penetapan formaldehid}

10 gram masing-masing sampel dilarutkan dengan aquadest $50 \mathrm{~mL}, 1 \mathrm{~mL}$ HClp dan $1 \mathrm{~mL} \mathrm{H}_{3} \mathrm{PO}_{4} 10 \%$, kemudian didestilasi pada suhu $100^{\circ} \mathrm{C}$ dengan menggunakan labu destilasi untuk mendapatkan hasil destilasi yang mengandung formaldehid.

1. Sebanyak $10 \mathrm{~mL}$ larutan standar formaldehid 5,0 ppm dicampurkan dengan $10 \mathrm{~mL}$ destilat dimasukkan ke dalam erlenmeyer yang telah diberi kode. Sebanyak $1 \mathrm{~mL}$ reagen Schiff's kemudian ditambahkan ke dalam erlenmeyer dan $1 \mathrm{~mL} \mathrm{H}_{2} \mathrm{SO}_{4}$ (1:1) yang telah berisi destilat sampel tadi (berwarna ungu muda). Homogenkan larutan dan diamkan selama 25 menit. Larutan di ukur absorbansinya menggunakan spektrofotometri pada panjang gelombang $570 \mathrm{~nm}$. Kandungan formaldehid dalam sampel dapat diketahui dari kurva kalibrasi dengan membuat plot dari absorban dan konsentrasi formaldehid standar dan hasilnya dinyatakan dalam $\mathrm{mg} \mathrm{L}^{-1}$ dalam setiap sampel yang diujikan.

\section{HASIL DAN PEMBAHASAN}

Hasil analisis kandungan formaldehid dari sampel minuman kemasan PET dan HDPE dengan interval waktu penyimpanan mulai dari waktu dipasarkan sampai masa kadaluarsa dapat dilihat pada Tabel 1. 
Tabel 1. Hasil analisis kandungan senyawa formaldehid dalam minuman yoghurt, minuman berkarbonat dan air mineral pada kemasan PET

\begin{tabular}{ccccccccccccc}
\hline $\begin{array}{c}\text { Waktu } \\
\text { ( hari) }\end{array}$ & $\begin{array}{c}\text { Sampel } \\
\mathrm{A}\end{array}$ & $\mathrm{mg} / \mathrm{l}$ & $\begin{array}{c}\text { Samel } \\
\mathrm{B}^{*}\end{array}$ & $\mathrm{mg} / \mathrm{l}$ & $\begin{array}{c}\text { Waktu } \\
\text { (hari) }\end{array}$ & $\begin{array}{c}\text { Sampel } \\
\mathrm{C}\end{array}$ & $\mathrm{mg} / \mathrm{l}$ & $\begin{array}{c}\text { Waktu } \\
\text { (hari) }\end{array}$ & SampelD & $\mathrm{mg} / \mathrm{l}$ & $\begin{array}{c}\text { Sampel } \\
\mathrm{E}\end{array}$ & $\mathrm{mg} / \mathrm{l}$ \\
\hline 0 & $\mathrm{~A}_{0}$ & $\mathrm{ttd}$ & $\mathrm{B}_{\mathrm{o}}$ & $\mathrm{ttd}$ & 0 & $\mathrm{C}_{0}$ & $\mathrm{ttd}$ & 0 & $\mathrm{D}_{0}$ & $\mathrm{ttd}$ & $\mathrm{E}_{0}$ & $\mathrm{ttd}$ \\
10 & $\mathrm{~A}_{1}$ & $\mathrm{ttd}$ & $\mathrm{B}_{1}$ & $\mathrm{ttd}$ & 30 & $\mathrm{C}_{1}$ & $\mathrm{ttd}$ & 7 & $\mathrm{D}_{0}$ & $\mathrm{ttd}$ & $\mathrm{E}_{1}$ & $\mathrm{ttd}$ \\
20 & $\mathrm{~A}_{2}$ & $\mathrm{ttd}$ & $\mathrm{B}_{2}$ & $\mathrm{ttd}$ & 60 & $\mathrm{C}_{2}$ & 0,05 & 14 & $\mathrm{D}_{0}$ & $\mathrm{ttd}$ & $\mathrm{E}_{2}$ & $\mathrm{ttd}$ \\
30 & $\mathrm{~A}_{3}$ & $\mathrm{ttd}$ & $\mathrm{B}_{3}$ & 0,72 & 90 & $\mathrm{C}_{3}$ & 0,44 & 21 & $\mathrm{D}_{0}$ & $\mathrm{ttd}$ & $\mathrm{E}_{3}$ & $\mathrm{ttd}$ \\
40 & $\mathrm{~A}_{4}$ & $\mathrm{ttd}$ & $\mathrm{B}_{4}$ & 1,43 & 120 & $\mathrm{C}_{4}$ & 0,67 & 28 & $\mathrm{D}_{0}$ & 0,02 & $\mathrm{E}_{4}$ & 0,06 \\
50 & $\mathrm{~A}_{5}$ & $\mathrm{ttd}$ & $\mathrm{B}_{5}$ & 1,67 & 150 & $\mathrm{C}_{5}$ & 1,07 & 30 & $\mathrm{D}_{0}$ & 0,23 & $\mathrm{E}_{5}$ & 0,27 \\
60 & $\mathrm{~A}_{6}$ & $\mathrm{ttd}$ & $\mathrm{B}_{6}$ & 2,87 & 180 & $\mathrm{C}_{6}$ & 2,31 & 35 & $\mathrm{D}_{0}$ & - & $\mathrm{E}_{6}$ & - \\
70 & $\mathrm{~A}_{7}$ & 1,48 & $\mathrm{~B}_{7}$ & 3,25 & - & $\mathrm{C}_{7}$ & - & & $\mathrm{D}_{0}$ & - & $\mathrm{E}_{7}$ & - \\
\hline
\end{tabular}

Keterangan: Sampel A = yohgurt, $\mathrm{C}=$ minuman berkarbonat. $\mathrm{D}$ dan $\mathrm{E}$ air mineral dengan kemasan PET. dan B* yoghurt dengan kemasan HDPE

Dari tabel 1, secara umum terlihat bahwa minuman yang dikemas dengan plastic PET terjadi peningkatan kandungan formaldehid dalam minuman selama penyimpanan, dimana semakin lama penyimpanan maka kandungan formaldehid semakin besar hal ini menunjukan terjadinya migrasi atau pelarutan monomer kedalam minuman. Terjadinya migrasi ini sangat dipengaruhi oleh sifat minuman dan kondisi lingkungan.

Untuk minuman yoghurt (A) yang disimpan dalam PET sampai penyimpanan 60 hari formaldehid belum terdeteksi, namun pada 70 hari formaldehid terdeteksi sebesar $1,488 \mathrm{mg} / \mathrm{L}$. Sedangkan yoghurt (B) yang disimpan dengan HDPE formaldehid sudah terdeteksi pada penyimpanan 30 hari sebesar $0,7 \mathrm{mg} / \mathrm{l}$. Pada hari ke 60 meningkat menjadi $3,25 \mathrm{mg} / \mathrm{l}$. Terjadinya migrasi formaldehid ini dalam minuman yoghurt bisa timbul akibat dari proses fermentasi bakteri Lactobacillus bulgaricus dan Streptococcus thermophilus yang dapat menghasilkan asam. Apabila minuman yoghurt disimpan dengan jangka waktu lama maka kandungan asam menjadi meningkat sehingga dapat teroksidasi dan membentuk senyawa aldehid diantaranya asetaldehid, formaldehid dan lain-lain. Dari tabel juga terlihat bahwa migrasi pada HDPE lebih cepat dibanding PET hal ini disebabkan oleh 2 faktor, yaitu kemasan HDPE dibuat dari proses polimerisasi adisi dari gas etilen, yang memiliki berat jenis dan tingkat transmisi oksigen yang tinggi, degradasi dan komposit dari plastik HDPE lebih besar daripada PET. Akibatnya HDPE mempunyai pori-pori yang lebih banyak daripada PET. Adanya pori-pori mengakibatkan mikroorganisme dan kandungan asam yang tinggi mampu memutuskan monomer lebih banyak dan membentuk ikatan yang memiliki berat molekul yang rendah salah satunya terbentuk senyawa formaldehid. Disamping hal diatas mungkin juga disebabkan kurang terkontrolnya kondisi suhu dan tekanan selama proses pembuatan kemasan, kemurnian bahan baku dan distribusi yang kurang memuaskan sehingga monomer dapat terbentuk dalam kemasan minuman dan menyebabkan terbentuknya kandungan asetaldehid dan formaldehid yang lebih cepat.

Pada minuman berkarbonat kandungan formaldehid mulai terdeteksi pada penyimpanan 20 hari dan meningkat samapai $2,31 \mathrm{mg} / \mathrm{l}$ pada hari ke 60 . Hal ini terjadi karena pembentukan formalin juga terjadi akibat terjadinya reaksi dari karbonmonoksida dengan air dalam keadaan anaerob, selain itu juga juga terjadi karena adanya tekanan mengakibatkan tegagangan 
pemukaan palstik semakin besar yang akan memicu pembentukan monomer semakin cepat. Hal yang sama juga terlihat pada air mineral yang terpapar matahari secara langsung, pembentukan formaldehid lebih cepat karana panas akan mengakibatkan reaksi termal akan terjadi lebih cepat.

\section{KESIMPULAN}

Berdasarkan hasil penelitian terhadap kandungan formaldehid terhadap minuman yoghurt, minuman berkarbonat dan air mineral dapat disimpulkan,

1. Adanya migrasi formaldehid dari kemasan kedalam minuman selama penyimpanan.

2. Untuk minuman yoghurt dan minuman berkarbonat penyimpanan sampai 50 hari formaldehid belum terdeteksi

3. Untuk minuman dalam wadah PET pada penyimpanan 60 hari kandungan formaldehid dalam yoghurt $1,488 \mathrm{mg} / \mathrm{l}$, minuman berkarboonat $2,33 \mathrm{mg} / \mathrm{l}$, yoghurt dalam HDPE 3,25 $\mathrm{mg} / \mathrm{l}$. Kandungan ini telah melebihi batas ambang yang sudah ditetapkan ditetapkan oleh tiga lembaga organisasi di PBB yaitu ILO, UNEP serta WHO yaitu $1 \mathrm{mg} / \mathrm{L}$ yang boleh masuk ke dalam tubuh manusia

\section{DAFTAR PUSTAKA}

Indriani, D. P., Hanifa Marisa, dan Zakaria. 2009.'Keanekaragaman Spesies Tumbuhan Pada Kawasan Mangrove Nipah (Nypa fruticans Wurmb.) di Kecamatan Pulau Rimau Kabupaten Banyuasin Sumatera Selatan." Jurnal Penelitian Sains, Volume 2 Nomor 3(D) 12309.

Duncan, S. Joseph, E and Timothy, L. 2000. Effect of Shelf-life and Light Exposure on Acetaldehyde Consentration in Milk
Packaged in HDPE and PETE Bottels. Thesis. Virginia Polytechnic Institute and State Univesity, Blacksburg.

EPA. 2007. Formaldehyde Teach Chemical Summary. (http://www.epa.gov/teach/). Akses pada tanggal 18 Januari 2011.

Kusumawati dan Trisharyanti. 2004. Penetapan Kadar Formalin Yang Digunakan Sebagai Pengawet Dalam bakmi Basah Di Pasar Wilayah Kota Surakarta. Jurnal Penelitian Sains \& Teknologi. 1(5): 131-140.

Redzepovic, A. Marijana M. Acanski. Vera L. 2011. Determination Of Carbonyl Compounds (Acetaldehyde And Formaldehyde) In Polyethylene Terephthalate Containers Designated For Water Conservation. Scientific Paper, Serbia.

Saidah, S. 2010. Daya Adsorpsi Wadah Plastik terhadap ion $\mathrm{Pb}$ dan $\mathrm{Cd}$ dalam air. Skripsi. Universitas Riau, Pekanbaru.

Sulchan, M dan Nur, E. 2007. Keamanan Pangan Kemasan Plastik dan Styrofoam. Majalah Kedokteran Indonesia. 2(57).

Tsai, C., Lee, S., and Chou, S. 2003. Determination of Low-molecule weight Aldehydes in Packed Drinking Water by HPLC. J.food and drug analysis. 2(1) 46-52.

Uzairu, A., Yiase, S.G., Ugye T.J., and Anhwange, B.A. 2010. Formaldehyde Levels In Some Manufactured regular Foods In Makurdi, Benue State, Nigeria. Journal Of Applied Sciences in Enviromental Sanitation. ISSN 19786980: 211-214.

World Health Organization. 2002. Formaldehyde. Concise International Chemical Assessment Document 40, Geneva. 